ESJ Humanities

\title{
The Role and Impact of the Islamic Religion on the Auchi Kingdom in Nigeria Since 1914
}

\author{
Suleiman Yakubu, PhD Student \\ Institute of Historical Sciences, University of Pardubice, Czech Republic
}

Doi:10.19044/esj.2021.v17n28p1

Submitted: 05 May 2021

Accepted: 28 July 2021

Published: 31 August 2021
Copyright 2021 Author(s)

Under Creative Commons BY-NC-ND

4.0 OPEN ACCESS

Cite As:

Yakubu S. (2021). The Role and Impact of the Islamic Religion on the Auchi Kingdom in Nigeria Since 1914. European Scientific Journal, ESJ, 17 (28), 1.

https://doi.org/10.19044/esj.2021.v17n28p1

\section{Abstract}

Academic discourse on religion and inter-group relations over the years has been trending in Nigeria. This is due to several cases of inter-ethnic and inter-religious conflicts witnessed in multi-cultural and ethnic Nigeria. The paper argues that despite the escalating ethnic and religious crisis the Islamic religion had played significant roles in the lives of the people of the Auchi kingdom since 1914. It also affirms the view that, as far as Islam is concerned, there were transformative roles the religion played in the lives of the people since 1914 till date. A high level of cordial inter-group relations has been achieved between the Auchi Kingdom and neighbouring communities, owing to inter-communal mechanisms of the same religion and similar culture over the years of interaction. The Islamic religion, which preaches peace, has become interwoven with the cultural practices of the people of the Auchi Kingdom This paper relies heavily on primary and secondary sources. Consulted written sources were cross examined.

Keywords: Islam, Religion, Muslim, Deities and Kingdom

\section{Introduction}

Islam is one of the main political and social forces in many parts of the African continent, south as well as north of the Sahara. The Muslim population in black Africa proper is more widely distributed and uneven. Black Africa may be regarded as a major Islamic world theatre (Kokole, 1993). In the next half century or so, according to a report that builds on the Pew Research 
Center's original population growth projections for religious groups, Christianity's long reign as the world's largest religion may come to an end. Indeed, Muslims will grow more than twice as fast as the overall world population between 2015 and 2060 and, in the second half of this century, will likely surpass Christians as the world's largest religious group (Michael, 2017).

This article is intellectually anchored on what we term an African experience of esotericism, with an emphasis on religion as an agent of change and innovations. In Africa, religion, mysteries, spiritualities and belief systems, like in most other parts of the world, permeate the culture and way of life of a people. The employment of supernatural aid or assistance in carrying out everyday activities has been a practice among indigenous African people. The real keynote of the life of the African is neither their noble ancestry nor the past deeds of their heroes, but their religion and belief systems. Religion forms the foundation and the all-governing principle of life for them. Many people of different African backgrounds and ethnicities subscribe to the idea of mystical or supernatural beings influencing the course of their lives, vocations or careers (Idowu, 1962).

In much of traditional Africa, that is, communities within the African continent where diverse traditional beliefs and practices, including ethnic religions still hold sway, people tenaciously hold on to the view that the full responsibility of all affairs of life belong to the deity; their own part in the matter is to do as they are ordered through the priest and diviners whom they believe to be the interpreters of the will of their deity. African religious beliefs and practices imply that a man's or woman's destiny is ordered and controlled by supernatural elements. Analogous mysteries and belief systems exist among the Africans, Indians Asians, Native North Americans, just to mention a few other peoples, whose spiritualities find expression in their everyday life (Idowu, 1962).

Searching for truth and sound theory is no easy task. It is quite ironic that today we have more good information available to us on history, and, at the same time, could be misleading (Richard, 2013). There are quite a number of questions that have been asked over the years that this article aims to address. These include how did Islam attain such an important role in this vast area? In addition, what special characteristics has Islam impacted on the Auchi Kingdom in Nigeria? These questions are asked in other to understand the interactions between Islam and the Auchi Kingdom of particular interest. There is also the question of whether or not Islam was innovative in the Auchi Kingdom. Thus, the paper focuses on the impact and the role of the Islamic religion on the Auchi Kingdom. We shall also examine the adaptability of culture of Islam, the role of the Nupe people in the Islamification of the people of the Auchi Kingdom, Islamic education, Islamic culture and practices in the 
Auchi Kingdom. In essence, this research examines the role and impact of the Islamic religion on a multi-dimensional African society and how it might impact the future of the people of the Auchi Kingdom.

\section{Methodology}

The African experience of esotericism constitutes, for this study, an "active agency" and a valid field of intellectual contemplation that provides an enduring context for explaining the intersections between the realms of creativity and spirituality in the role of the Islamic religion in the activities of the everyday life of the Auchi people. During the course of the research relevant historical documents, books, etc. were sourced from private and public libraries. Websites were analysed, and systematically deployed in the study. One of the greatest challenges as a historian was most pronounced during the process of oral interviews. Oral sources are the greatest reference point for the reconstruction of African history. ${ }^{1}$ The researcher's genuine intention of going into this aspect of field-work was not only misconstrued but was also very tasking. Difficulties of carrying out the research includes, getting in contact with the ideal people for the interviews, getting to the locations of the interviewees ${ }^{2}$ and constraints caused by the COVID pandemic situation. ${ }^{3}$ However, prospective participants were typically willing to participate. The research was carried out with the conducting of semistructured, structured and unstructured interviews. Basic demographic information, including age, religion and marital status were collected from participants.

For the purpose of this research primary and secondary sources were consulted. The analysed books were written by both Auchi indigenes and non Auchi indigenes. This was done to have a balanced view of the history of the Auchi Kingdom which provided evidence of the credibility of its history. In this vein, it is worthwhile to note that throughout the research I decided to analyse not only personal narratives, but also the attitude, behaviour, mindset and age of participants in order to identify discrepancies in their narratives. All the data gathered were qualitatively analysed.

${ }^{1}$ Oral tradition is a primary source of African history and It is very important in the reconstruction of African history. There is a lot of invaluable historical information that predates the art of writing and such information cannot be found in any written document but is handed down from generation to generation by words of the mouth. Without oral tradition only little will be known of Africa history.

${ }^{2}$ Many of the interviewees are located in rural areas and reaching them was quite difficult but it was eventually possible after much determination and great effort.

${ }^{3}$ The Coronavirus pandemic situation affected a lot of events and activities worldwide but the interviewee still agreed to be interviewed because some of them knew my late father personally. 


\section{Origin and geographical location of the Auchi Kingdom}

Auchi, which is today one of the five clans that make up Etsako West Local Government Area of Edo State, is located at latitude 7.6 N and longitude 6.13 E (Boateng 1959, 22). The Auchi Kingdom is in the Savanna forest area. The tropical rain forest which covers most of Edo State of Nigeria begins from Auchi (Seghosime, 2011). Over the years, the Kingdom has, at various times represented the headquarters of different divisional authorities such as Kukuruku vassalage under the Bida emirate (1860-1897), the Afenmai division (formerly known as the Kukuruku division until 1954) at the dawn of British colonial rule, and as headquarters of Etsako Local Government Area upon the creation of the Mid-Western Region in 1963. Following the return to civilian rule in 1979, the Kingdom became the headquarters of the Bendel North Senatorial District. Today, Auchi is the headquarters of the Etsako West Local Government Area following the creation of new States and Local Government Councils in Nigeria on August 27, 1991. ${ }^{4}$ Despite this, it still retains a senatorial district position, but now of Edo north. This Kingdom is bounded in the north by the Uzairue Clan, South Ibie Clan in the east, the Aviele clan in the south and the Ivbe-Adaobi clans in the west; all in Edo state. Thus, the Auchi, among other Afenmai towns is situated in the northern area of the present-day Edo State of Nigeria and its inhabitants speak the Etsako dialect of Edo language. Auchi's vegetation is a Guinea Savannah and this is why the area is reputed with wave-like landscape and physical features which includes hills, valleys and mountains with caves (Oseni, 2020).

The soil in Auchi is also rich for the growth of grains such as millet, beans, rice, maize, among others as well as a variety of fruits. One important river that flows across Auchi is the river Orle which has its starting point in a spring in a cave around the suburb of Dangbala town (in, the Akoko-Edo Local Government Area of Edo state) and flows to Aviele clan where it is joined by river Edio as a tributory. Still bearing the name, Orle, the river flows directly to Anegbete Clan, now in Etsako East Local Government Area, where it joins River Niger, the widest and longest river in West Africa. The central position of Auchi as well as her easy accessibility to most parts of other Afenmai land gave her an advantage, allowing her to serve as a divisional and local

\footnotetext{
${ }^{4}$ More information on the villages and clans of the Auchi Kingdom. The five great villages are Utsogu, Akpekpe, Aibotse, Igbhei and Iyekhei. Other neighbouring towns in Etsako West local government area close to the Auchi kingdom include Uzairue, South Ibie, Agbede and the Anwain Clan. During the British colonial rule, the Auchi Kingdom was the headquarters of the Kukuruku Division, which was the former name of Afenmai land. The settlement was a splendid choice for the initial settlers. The town is close to about twenty rivers, rivulets and springs such as Orle, Omemhe, Ofhotsele, Eda Ibariki, Ukpheleghi, Eda Nokhua (Utsogu), Eda Nokhua (Aibotse), Amasomhe, Umhouku, Ayeda, Ayeda-Aminu, Eda Udo, Eda Oke, Eda Ayomhe, Oki, Arhebekpeghie, Edo Ofoli, Ikpaigba. and Eda-Egini.
} 
administrative headquarters from the earliest times, especially since $1920 .^{5}$ Apart from the fact that the town has good roads which link it with other Edo state communities, it is also linked with neighbouring states like Kogi state in the north and Ondo state in the West and north-west. Perhaps, this strategic location of Auchi and its administrative status from primordial times is responsible for her growing population, which in turn welcomes buoyant commercial activities (Obomeghie, 2020).

The indigenous society of the Kingdom was founded between 1481 and 1500 by a man from the Benin Kingdom known as Uchi, the progenitor (Ikharo, 1981). Uchi was a warrior prince who migrated from Udo in the present day Ovia Local Government Area of Edo State. His migration was triggered by a dispute with his brother, the Oba of Benin, over the right to keep a leopard's skin. The leopard was then regarded as a royal beast and political totem. ${ }^{6}$ It was customary at that time that anybody that killed a leopard was to surrender the skin of the animal to the Oba. Uchi killed a leopard and refused to surrender the skin to the Oba. He felt the law regarding the surrendering of leopard skins to the Oba did not apply to him because he was a prince and the rule was meant for only commoners. The Oba, very angry, relieved Uchi of his command of the western defenses of the Benin Kingdom. Relieved of his duties, Uchi was recalled to Benincity where he stayed at Ogbe quarters with his family members (Robson 2016, 2). Uchi feared for his life because he felt the plot by the Oba against him had thickened. He decided to flee the Benin Kingdom for safety. Udo and his followers hatched a plan to flee from the Benin Kingdom. The secret code amongst the people that agreed to flee with him was "UNA EGBIA, UNA LE" meaning "EARLY MORNING, IT IS RUNNING". Whenever Uchi's emissary entered a compound on the appointed day and called out "Una Egbia" people in the compound who were faithful to the escape plan responded "Una le". This was how Auchi got its good morning greetings "UNA GBBIA, UNA LE" and this has remained our early morning greeting till date (Aruna, 2010).

Emigration from the Benin Kingdom took place in the fifteenth century. After a very long trek and search for a suitable place to settle, Uchi and his followers settled at a place about 130 kilometers away from the Benin

\footnotetext{
${ }^{5}$ It is worthy to note that before the Auchi kingdom was overrun by the Nupe in 1860 it was a central trading location for the whole of Afenmai land. Traders came from within and beyond Afenmai to carry out trading activities. Also, the Auchi Kingdom due to its strategic central location, was used as a garrison for the safekeeping of slaves before they were transported to Nupeland.

${ }^{6}$ Totems are very important in almost every African community. They could be sacred animals or plants. It is also worthy to note that in almost every community in Africa there are both biological and political totems. These totems may not be killed or harmed. Anybody that killed such animals was punished or fined. It is still very much in existence in most communities in Africa.
} 
Kingdom on the top of a hill just behind the present-day Guarantee Trust Bank (GTB). A market developed in and around the location that Uchi and his followers settled. The market is known as "Aku-Uchi” (Uchi Market). The market is still in existence and remains the biggest market in Auchi. Over the years after the demise of Uchi, he was deified and a shrine was built on Uchi's first place of settlement at Uchi Market. Worshippers of the Uchi deity go to the shrine with native chalk and salt and make requests believing strongly in the potency of the Uchi diety. The shrine was eventually destroyed and uprooted in an upsurge of the spread of the Islamic religion in 1914 (Momoh, 2016).

Essentially, the prevalent traditions of origin among the people of present-day Auchi Kingdom is emigration from the Benin Kingdom. Although their society was an offshoot of the Benin Kingdom, over time they developed distinctive cultural features that set them apart. These features are noticeable in their language, system of government, traditional religion, and the title system. The most outstanding of these features was the absence of a rigid centralized authority and allegiance to one venerated ruler, which was the hallmark of the Benin traditional polity. Some traditional features of the Auchi Kingdom underwent considerable alterations as a result of "foreign contact". The main external impetus for change was the Nupe invasion in the late nineteenth century before the eventual imperialism of the British in 1897 (Erhagbe, 1982).

\section{The Auchi Kingdom during the pre-Islamic period}

In all countries in Africa either or both of the two world's most popular religions, Christianity and Islam, is practiced. ${ }^{8}$ These two religions, however, are external influences, (Oseni, 2020) introduced into the countries of Africa by foreigners. It must also be said that most African countries still practiced their indigenous and traditional religions alongside Islam and Christianity. Africans had their own means of worshipping whatever deity that they believed in before the coming of Islam. Africans were basically animist and polytheist. The Auchi Kingdom situated in the western part of Africa, was in this regard, no exception. Before Islam was introduced in the Auchi Kingdom, the people had many deities they trusted, worshipped and begged for

${ }^{7}$ The coming of the Nupe altered the system of government and way of life of the Auchi people. The arrival of the Europeans further saw the introduction of strange influences which were, for Africans, strange. These included new religion, culture and language. This included their way of life and religion that this altered the traditional African way of life

${ }^{8}$ It is worthy to note that one would find Muslims and Christians in all the countries in Africa. There are people that practice only the Islamic religion or Christianity and there are the traditionalists that practice only the African traditional religion. There are also some people that combine and practice both the Islamic religion and the traditional religion or Christianity and the African traditional religion (syncretism). 
assistance in an innocent manner. Such deities included Uchi (the spirit of the founder of Auchi), Orle (the River goddess), Amanue, Ogholodio, etc. These deities had shrines built for them where they were worshiped by their devotees. At that time, traditional religion was the official religion of the Auchi people. In fact, each village and community in the Auchi Kingdom had its shrine where the people worshipped (Momoh, 1995).

The People of the Auchi Kingdom had a strong belief in a supreme God. In the local dialect of the people God was called by names such as "Oghena" and "Ogie Okuli". The people recognized the uniqueness of the supreme God in their common prayers when his name was mentioned. They also had belief in the absoluteness of God's control of the universe and the universality of God. One major proof of the Auchi people's belief in the uniqueness of God was the fact they called on the superior God through the smaller gods to protect them from the hands of the evil doers. Moreover, because of their belief in the absoluteness of God's control over the universe and the universality of God. The Auchi people were convinced God, as the creator of the universe, was and still is the main cause of whatever human or spiritual power that existed in any part of the universe. Hence, he was regarded as the only God in the entire universe (Idowu 1973).

Also, the Auchi people had belief in local divinities There were divinities that were worshipped collectively by the people of the Kingdom and there were other divinities that were worshipped by individual members of various extended families of the Kingdom. ${ }^{9}$ However, many of these local divinities, particularly the clan and village deities, represented some of the early Auchi men and women that were deified by their respective families for their phenomenal contributions towards the early contributions towards the growth and protection of the kingdom. One such local deities was Orle, the River Goddess. This deity was known to be the goddess of fertility. Another one was Uchi, the progenitor of the Auchi kingdom. It is believed that Uchi migrated from the Benin Kingdom over five hundred years ago and settled in present day Auchi. The Auchi people did not offer human sacrifice to their local deities. Rather, they utilized certain domestic animals such as goats, sheep, cocks and ducks. Also, they offer certain foods, particularly pounded yam and egusi (melon) soup, to such deities as sacrifice. Apart from ensuring

${ }^{9}$ There basically many gods worshipped by the Auchi people. The major gods were orle, ogun, adaobi etc. These were worshipped collectively by everyone in the Auchi kingdom. There were other gods or local juju that were worshipped by members of an extended family. This local juju was known as oloko and it was offered sacrifice from time to time. The sacrifice could be cocks, local gin or sometimes just water. When the custodian of the local juju dies or was too old to carry out his duties, he is expected to transfer the juju to a much younger person to carry on with the role. The local juju is expected to pick its new custodian after much consultation and incantations by a powerful shrine priest. I witnessed one of such events some years ago in Nigeria. 
the wellbeing of the people, the deities assisted in curing women of the problem of infertility of the womb. The deities were also used in performing some quasi-judicial functions. Among such disputes were those concerning alleged theft, alleged sorcery, infidelity etc. Accused persons are made to swear to their innocence in the shrine of the local deity and the result was received within a very short period. ${ }^{10}$ However, despite all these processes and methods of deifying and veneration of the local divinities in the Auchi kingdom, the basic concept of religious beliefs and practices remain very similar within Africa (Arunah, 2010).

Again, the pre-Islamic Auchi people believed in the existence of spirits and ancestors. They believed that spirits, in some cases, used material objects as temporal abodes to manifest their presence and actions. In most cases for example, when a person's farm is destroyed by unseen forces it was believed that the spirits were responsible. It usually resulted in the intervention of certain stronger spiritual forces such as native doctors and medicine men to control their activities. There was also a general belief that the dead play a very significant role in the lives and activities of the living. Hence, they strongly believed in their ancestors. It was not every important man or woman that was deified as an ancestor. Most communities in Africa had their ancestors who were usually the founder and progenitor of the Kingdom. After the deification of a person, such a person emerges as a central figure in the religious system and practices of the people. Moreover, shrines and places of worship are built in their honour and memory because they are highly venerated. It is very important to note that all the ancestors in African communities are addressed in prayers, songs and epithet. ${ }^{11}$ In this way, such ancestral spirits helped to ensure peace, good harvest, fertility of women and peaceful coexistence of the people of the Kingdom before the Nupe invasion of 1860 (Obomeghie, 2020).

Furthermore, there were certain religious festivals that were organized to pay respect and give honour to the ancestral spirits of their progenitor and other deities because it was believed that they had significant roles to play in the lives of the people of the kingdom. These festivals were performed at specific times of the year. These festivals were performed for some major purposes. These included to pay respect and make certain requests from the

10 This means of administering justice was very effective during the precolonial era. The outcome was very swift and accurate. Sometimes, the punishment could be very severe. Many people, when they knew that they were guilty, confessed before the outcome of the divine consultation and the pleaded for forgiveness. This act of administering justice is very crude but is still used in some local communities in Africa

${ }^{11}$ This is still very much practiced in the Auchi Kingdom. Orle is very much venerated by her followers in the Auchi Kingdom despite their being Muslims. They believed that it was faster to get solutions to problems or very pressing issues and they had great belief in the potency of the divine power of orle. 
Almighty God, to celebrate some major or important landmarks in the people's history and evolution and help to affirm cultural resolutions. Also, it made it possible for people to socialize. It was believed that this was possible through the assistance of ancestral spirits which acted as an intermediary between God and the people.

One such festivals was the Uchi festival which was held in the honour of Uchi, the Auchi people's ancestral father and founder of the Auchi Kingdom. During the festival, everybody, especially women and children, came out in festive moods. They all went to the place where Uchi settled when he arrived Auchi. This was the marketplace on the top of the Ekhei hill. They all clapped, sang and danced as they approached the venue. The local priest arrived and performed the propitiation rituals of the festivals. The people then thanked and made prayer requests to Uchi. It was believed that Uchi responded to the people through the local priest by thanking the people for their devotion and ensured them that their prayer requests would be answered (Oseni, 2020).

Another important festival during the pre-Islamic period was the orle festival in Auchi. This festival, like the first one, encouraged the active participation of all the Auchi people. However, women and children usually comprised the majority of those who came out during the feast. One reason for the leading role of women in such festivals was that the Etsako cultural system encouraged them to act as seekers of cosmic protection for their communities. It was, in fact, believed that because of their relatively weak outward appearances coupled with their milk of human kindness that they would be able to influence the ancestral spirits to help the people out of difficult situations. Besides, many of such festivals were believed to help women to enhance their power of procreation. With the introduction of the Islamic religion, many of these festivals were stopped and some others became just mere celebrations that were marked without propitiation rituals (Momoh, 2020).

Furthermore, in the Auchi Kingdom and other Nigerian communities, magic medicine and religion were virtually inseparable. Hence, they were all interwoven before the introduction of Islam in the twentieth century. As it was in other communities, the people of the Auchi Kingdom strongly believed that the basis for any natural or supernatural phenomena or happening was a spiritual power or force behind it. As a result of this belief, any Auchi person who had problems consulted native doctors and marabouts for solutions to their problems. These native doctors and marabouts used different divinatory methods and items such kolanuts, cowries, palm kernel shells etc in consulting the oracle. During the consultation, incantations are made and the cause of the person's problem is revealed to the marabout. He is also able to disclose who inflicted it, how it would be treated and the items that would be used for the treatment. Sometimes, marabouts and native doctors were consulted to obtain 
potent charms and talisman for protection against witches and wizards. They provided charms for the warriors of the Kingdom to ensure their safety during the times of wars. It was generally believed that during those periods, the charms and local medicine administered by the marabouts on the people of the Kingdom made them to be fearless, brave, zealous and confident (Egbefo, 2020).

Additionally, the Auchi people believed in reincarnation and life after death. They believed in both the human and spiritual/invisible world. The nonhuman world is the world which we cannot see. These two worlds are not separated, but connected, and make up one continuous, complete world. This explains the West African belief in the never-ending cycle of life and reincarnation. ${ }^{12}$ They believed that when one is born, he grows old, dies after achieving his purpose on earth, and then is reborn. The visible world is a world of human beings, of natural forces and phenomena. The invisible world is a world of divine beings, of good and bad spirits, and departed ancestors. The visible and invisible worlds commune and interact with each other. The preIslamic Auchi people believed that there were spirits all around them. These spirits are too many for one to even know. The Auchi people had diviners, priests, priestesses to help explain the universe. These were special human beings who were endowed with spiritual idiosyncrasies and spiritual powers. They had the ability to communicate with the dead. They were the link between the dead and the living. It must be said, however, that this was contrary to the principles of the Islamic religion (Oseni, 2020).

\section{The introduction of the Islamic religion to the Auchi Kingdom in 1914}

The introduction of the Islamic religion to the Auchi Kingdom marked a turning point in the lives of the people. Islam was practiced in the Auchi Kingdom before 1860 but it was practiced only by visitors, strangers and travelers who were mainly of Nupe, Hausa, fulani, and Yoruba origins. It should be noted that the Nupe and Hausa settlers lived mainly at Aibotse, ${ }^{13}$ a village in the Auchi Kingdom. This is the main reason why the central prayer ground lies in Aibotse till this day. It has never been shifted from that area since the inception of Islam in Auchi. Despite the fact that the Nupe did not directly Islamize Auchi, the fact remains that interest in Islam and the Islamic revolution which took place in the area, subsequently, was the result of their conquest and socio-political interaction with the people of the Auchi Kingdom and neighbouring communities. Nupe mallams also contributed greatly to the Islamization process when the Auchi Kingdom and other communities decided to adopt Islam as their state religion. In view of the above-mentioned

\footnotetext{
${ }^{12}$ See "Abiku", a poem written by Wole Soyinka for more details on reincarnation.

${ }^{13}$ Aibotse is the name of the village where the first Otaru (King) of the Auchi Kingdom was coronated and decorated with the official regalia.
} 
reality, the role of the Nupe in the Islamization of Auchi cannot be brushed aside, but they were mainly interested in trade before the invasion of the Auchi Kingdom in 1860 (Tadaferua, 2020).

In 1914 a major event which had the character of a revolution took place in Auchi, in present day Edo state of Nigeria. This event was the adoption of Islam by the Auchi people as their official religion, and the overthrow of the old belief system initially upheld by the people. This ushered in a new era, and the quality and character of life then took on a new form. It was Oba Momodu of nearby Agbede town, ${ }^{14}$ which was very close to the Auchi Kingdom, who first embraced Islam in the area, and the Auchi Kingdom followed quickly in the wake of his action. Already incarnated in Auchi was one who, blessed with a cosmopolitan outlook and a friendly, helping nature which welcomed new ideas and initiatives, was to play a powerful role in the Islamisation of Auchi. This was Momoh the first, a dynamic prince of the Kingdom, loved by the British and his people and their neighbours, who initiated the reforms years before he even became the Otaru or King of Auchi (Momoh, 1995).

King Momoh was described as the person who encouraged the introduction of Islam in the Kingdom as he strived to draw converts to the new faith. He announced that the first 250 people to learn how to pray and killed a ram to have their names changed to Muslim names would be given a full set of Islamic clothes. It is this mode of dressing which makes Auchi look like a typical northern Muslim town. It is still in vogue at the Auchi Kingdom till the present day. After the first 250, Momoh declared the same prizes for another 350 , and many rushed to win the embroidered flowing gown, Sokoto and cap (Momoh, 1995). Momoh as a very young boy embraced Islam, and was always seen in the company of Hausas. He was a very enterprising young prince. He was a tailor, and he had a cotton farm and was trading up to Calabar, Lagos and Warri which were major cities in Nigeria. He was enlightened, and even got a private teacher to teach him how to speak and write in the English Language. ${ }^{15}$ He learnt how to read the Qur'an as a young person under the Hausas and the Nupe. Around 1910 he started the process by inviting mallams to the Auchi Kingdom. Some of them were already in Agbede helping Oba Momodu. He attracted some of these mallams to the Auchi Kingdom. Thus Momoh, alongside the Hausa, Nupe and Yoruba mallams, later destroyed the material representations of the gods whom the people had been worshipping

\footnotetext{
${ }^{14}$ Agbede town was the first town to adopt the Islamic religion as its official religion. Until today, the town has remained very active in the practice of the Islamic religion.

${ }^{15}$ King Momoh 's love for Western education made him enroll many of his children in schools where Western Education was taught. His lineage remains the most educated and influential in the Auchi Kingdom.
} 
over the centuries. By 1914 all the idols had been destroyed and the community accepted Islam fully (Oseni, 1995).

By 1919 when Momoh became Otaru he sent mallams to neighbouring villages and towns to preach and teach the gospel of Islam to the people, and so Islam now grew in a rich circle among communities in and around Auchi. Also, he married many wives from within and outside Auchi. He used marriage to cement relationships between Auchi and neighbouring towns. Some mallams were sent to Lokoja, Keffi, and Kano to study, and by 1960 there were many eminent mallams in the Auchi Kingdom. King Momoh had a total of forty-eight wives and two hundred and fifty-seven children. The British were impressed with the level of domestic harmony in King Momoh's household despite its large population. His words "The white men who were here as District Officers were all fascinated at how a man could rule people without a trace of quarrelling among them" (Momoh, 2020). The wives were organized in groups, with the older wives taking care of the younger ones as if they are children of the same mother. King Momoh was a fantastic family man. It is the belief of the Auchi people that adopting Islam as a state religion was the best things that happened to the Kingdom (Ujorha, 2020).

\section{The role and impact of the Islamic religion on the Auchi Kingdom}

The introduction of the Islamic religion to the Auchi kingdom, as stated above, was one of the best things that ever happened in the Kingdom. Islam had a great impact on the people of the Auchi Kingdom and the neighbouring communities. Firstly, Unlike Christianity, Islam is not just a religion or a mass of doctrines or beliefs and rituals, but rather a complete way of life or civilization. The religion is one that covers all aspects of human life. To this end, it ushered in innovations as well as becoming the state religion and it also modified the cultural life of the people of the Auchi kingdom. Islam means "total submission to the will of God". The religion preached peace, and this subsequently modified the religious life and cultural practices of the people of the Auchi Kingdom. This, to a very large extent, created peaceful co-existence amongst the people of the Kingdom and neighbouring towns and communities (Robson 1996).

Secondly, it was also a revolution against the former belief system of polytheism, the belief in many gods. The People of the Auchi Kingdom accepted and began the Islamic practice of monotheism. Monotheism means a belief in the unity of God in every respect. Britannica's collegiate dictionary defines "monotheism" as the doctrine or belief that there is only one God. The belief in the Oneness of God and the worship of God alone is central to submission. In many places, in fact, we see the religion of submission being referred to synonymously as the religion of monotheism (Britannica's dictionary, 2020). Monotheism is a religious-philosophical term which 
indicates a belief in one personal creator, God, who is both inside and outside the universe. The various definitions of monotheism given by eminent scholars from time to time emphasize the creative and sustaining activity (Britannica's dictionary, 2020). This became the new belief system of the Auchi people in 1914.

Thirdly, the Auchi Kingdom adopted the Muslim system of justice and taxation. ${ }^{16}$ Thus, Islam also promoted a more efficient administration. It enabled the rulers to employ educated Muslims as secretaries, administrators, judges and diplomats and also to correspond with provincial rulers and administrators. The current secretary to the Otaru of the Auchi Kingdom is a polytechnic graduate of secretarial studies. ${ }^{17}$ Crucial matters of the Kingdom are discussed behind closed doors and references are also made to the provisions of the Holy Koran. ${ }^{18}$ When decisions are carried out references are also made to the Koran. It must be said in whole that the decision-making system was generally based on the provisions of the Holy Quran since the adoption of the Islamic religion (Abass, 2020).

Fourthly, when the Islamic religion was adopted as the state religion, there was also the adoption of Islamic names as a means of identification and acceptance of the new religion. The Auchi Kingdom, before the introduction of Islam, conceived names as an emblem of identity. Before the Nupe invasion of 1860 when children were born, they were given traditional/Auchi names. These traditional names had inner meanings, and it was believed that the name given to a newly born child went a long way in sharpening the child's life in the future. Some of these traditional names and meanings include-

1. Oshiobugie- God shows the way.

2. Oshionebo- God is the granter of greater protection over evil

3. Ikelegbe- I do not want enemies (Oseni 1981, 15)

It is worthy to note that the people of the Auchi Kingdom gave their children Islamic names alongside traditional names after the adoption of Islam as the state religion. When children were born, they were given Muslim names on the day of their naming ceremonies, which is seven days after the child is born, to reflect their identities as muslims. Some of Islamic names and meanings includes-

\section{Basiru- The All seeing}

\footnotetext{
${ }^{16}$ The system of collecting tax was first introduced during the period that the Nupe established their imperial rule over the Auchi Kingdom. This was done to get finances that were taken back to Nupeland. When the Islamic religion was fully adopted as the state religion in 1914, the King fully adopted the Islamic taxation system and used it to retrieve tax for the British Colonial Government.

${ }^{17}$ I have met and conversed with him on several occasions. His name is Idris Yahaya.

${ }^{18}$ When crucial issues are being discussed in the Auchi Kingdom reference is always made to the Holy Koran. When problems are also brought before the King in his palace for judgement to be passed, reference is always made to the Holy Koran.
} 


\section{Rahim- The merciful}

3. Mumin-The custodian of faith (Oseni 1981, 18)

Until today, this has remained the common practice in the Auchi Kingdom since the introduction of Islam in 1914.

Additionally, the Islamic religion created unity between the Auchi Kingdom and her neighbouring communities. Islam cut across family, clan and ethnic ties and loyalties and emphasized unity and brotherhood. It enabled rulers to build larger kingdoms and empires embracing different peoples and linguistic groups. It also provided them with a commonly accepted basis of authority in place of African traditional religions which differed from place to place. Many of the rulers of communities outside the Auchi Kingdom were aligned together because the religion preached peace. ${ }^{19}$ They also used Islam in these ways to generate a feeling of unity and as a basis of their authority. It must, therefore, be noted that Islam was used as a basis for peaceful intergroup relations (Robson, 2016).

Furthermore, the Islamic religion brought about the learning and teaching of Koranic education and Arabic language. Before 1914, only a few people were privileged to acquire western education and the only available education was Koranic education. Islam introduced literacy as well as Islamic education. Literacy made it possible for scholars to preserve the history and the oral traditions of their community in books. Literacy and knowledge of the Arabic language also enabled the people to have access to the invaluable Islamic literature, sciences and philosophy which broadened their knowledge, improved their statecraft and widened their mental horizon. ${ }^{20}$ As Islam continued to spread throughout the Kingdom, Koranic schools and educational centers were established. This, to a very large extent, made the people have a wide knowledge of the religion and this made them to be better people (Obomeghie, 2020).

Lastly, the introduction of the Islamic religion to the Auchi kingdom influenced the dressing patterns of both the men and women. It should be noted that the basic requirements of the Muslim woman's dress apply as well as the Muslim man's clothing with the difference being mainly in degree (Badawi, 1973). The major thing is to ensure that the body is fully covered. The men in the Auchi kingdom usually put on flowing gowns known as the

\footnotetext{
${ }^{19}$ The Islamic religion preaches peace to the followers of the faith. During festive periods people within the Auchi Kingdom and beyond come together to observe prayers together and this creates a spiritual bond among the people.

${ }^{20}$ It is worthy to note that one learning how to read the Holy Quran also made him learn how to speak a new language, Arabic. In the absence of Western education, one could express oneself in Arabic language. It was a kind of literacy which offered people new knowledge and access to literature written in Arabic and information could also be preserved in Arabic Language.
} 
Kafftan and Jalabiyyah exposing only his hands and feet and he is always with a cap on his head. The Muslim ladies have the whole of their bodies covered up in their flowing gowns and their Hijabs (veil) to cover their hair and only their faces are exposed. It is highly prohibited for a Muslim lady to expose their hair in a public place. Most times the wives of prominent men were required to live in purdah (seclusion) and to veil their faces when they went out. This pattern and tradition of dressing in the Auchi kingdom is still in place till the present day (Oseni, 2020).

\section{Conclusion}

Islam is a religion of intellectuality, and also of love and charity. Islam gives honour and prestige to the human race and tries, in different ways, to imbue morality and piety in its members so as to facilitate their felicity. Faith in God, hope in Him, and above all love for Him, result in a profound submission to Him (Zahra ,2019). This, to a very large extent, has made the People of the Auchi Kingdom to be very religious and kind hearted people. Religion has changed their way of life in all endeavours. The religion also reflected in their mode of dressing and everyday life. That is not to say that the religion did not have some encroachments into the traditions and cultural antecedents of the people. The Auchi Kingdom's cultural and traditional values were greatly affected with the introduction of the Islamic religion in 1914 but it must be noted, however, that the introduction of the Islamic religion brought more good than harm. Bad aspects of the traditional practice such as idol worshipping, polytheism etc. was stopped. It must be noted that the role and impact of the Islamic religion had a positive impact on the Auchi kingdom since 1914 and it will continue to impact positively on the lives, morals and wellbeing of the people now and in the near future.

\section{References:}

1. Arunah, A, O., A history of Auchi Kingdom, Ilorin, Haytee Press and Publishing Co. Nigeria Ltd, pp. 18 - 19

2. Boateng, Ernest Amano, (1974), West African Secondary School Atlas New Edition, Lagos: Thomas Nelson Nigeria Ltd, p. 22.

3. Britannica's dictionary, (2020), Monotheism, Accessed on September 26, $2020 \mathrm{https}: / / \mathrm{www} \cdot$ britannica.com/topic/monotheism

4. Egbefo, Dawood, Omolumen, (2008), The Nupe Invasion of Esanland: An Assessment of its Socio-Political Impact on the People, 1885-1897, Haskenти Vol.1, 2007-2008, Faculty of Education and Arts Seminar Series, IBB University Lapai, Niger State. Nigeria, p. 75.

5. Erhagbe, Eddie, O, (1982). "Etsakoland in Transition, 1860-1948: An Analysis of Change in an Indigenous Nigerian Society", MA Dissertation, Department of History, University of Benin, Nigeria. 
6. Idowu, Bolaji, E, (1973), African Traditional Religion: A Definition, Maryknoll, New York, Orbis Books, p. 54

7. Idowu, Bolaji, E. (1962), Olodumare: God in Yoruba Belief. Ikeja: Longman Group Ltd, p. 32.

8. Ikharo, O. A, (1981), "The rounding and origin of Auchi Clan" Manuscript, no.1-11.

9. Jamal, badawi, (1973), "Women \& Men Dress in Islam," The Islamic Education \& Services Institute, Sabiq, Sayyid, Fiqhus-Sunnah, 2nd Printing, Darul-Kitab-il- Arabi, Beirut, Lebanon, p. 9, http://www.2discoverislam.com.

10. Michael, Lipka and Conrad, Hackett, 'Why Muslims are the world's fastest-growing religious group, ' a report by the Pew Research Centre on demographic progressions in the changing Global Religious Landscape, April 6, 2017.

https://www.pewresearch.org/fact-tank/2017/04/06/why-muslimsare-the-worlds-fastest-growing-religious-group/

11. Momoh, Tony, (1995), Each man, his time: the biography of an era, Lagos, Efua Media Associates, p. 36.

12. Omari H. Kokole, (1993), Religion in Afro-Arab Relations, Nigeria: spectrum Books Limited, 1993, p. 232

13. Oseni, Zakariyav Idrees-Oboh, (1998), The Islamization of Auchi Kingdom in South Central Nigeria in First Auchi Day, Lagos: Efua Media, no. 62, http://www.ikharoroyalfamily.com/wp-content/uploads/2015/08/TheIslamization-of-Auchi-Kingdom-in-South-Central-Nigeria.pdf

14. Oseni, Zakariyav Idrees-Oboh, (1981) A Guide to Muslim Names with Special Reference to Nigeria, Lagos, Islamic Publications Bureau, p. 15

15. Richard, Swanson. A, and Thomas, Chermack. J, (2013), Theory Building in Applied Disciplines, San Francisco, CA Berettkochler Publishers, p. 5.

16. Robson, Momoh, (2016), New perspectives on the history and politics of Nigeria: The Etsako, Experience, Edo: Afenmai Grafix, p. 113.

17. Seghosime, K. M, (2011), Origin and Development of Auchi, Auchi, Smilestel Global Digital, p. 3

18. Tadaferua, Ujorha, 2020, "Life of Momoh, Auchi's first Muslim King", Daily trust online Newspaper, Monday, May 4, 2020, https://www.dailytrust.com.ng/life-of-momoh-auchi-s-first-muslimking.html

19. Zahra, Khazaei, (2019), "The Role of Religion in Shaping Moral Character: An Islamic Perspective", Department of Philosophy Qom 
University, Iran, 08 May 2019, no. 6, https://www.researchgate.net/publication/327727871, Interviews

20. Egbefo, Dawood, Omolumen, (Professor, 55 Years Old, Married, Muslim, interview on 21 August, 2020 at Iyamu, Edo State, Nigeria).

21. Ibrahim, Abass, (Teacher, 60 Years Old, Married, Muslim, interview on 20 July, 2020 at Auchi, Edo State, Nigeria)

22. Momoh, Tony (Journalist, Lawyer and Former Federal Minister of Information in Nigeria, 81 Years Old, Grail Messenger, Interview on 15 October, 2020 at Lagos State, Nigeria).

23. Obomeghie, Wajeed (Journalist and writer, 54 Years Old, Married, Muslim, interview on 14 August, 2020 at Abuja, Nigeria).

24. Oseni, Zakariyav Idrees-Oboh (Professor of Arabic and Islamic Studies and Researcher, 71 Years Old, Muslim, Interview on 13 June, 2020 at Ilorin, Kwara State, Nigeria). 